TITLE:

TWO NEW GAMMARIDEAN AMPHIPODS (CRUSTACEA) COLLECTED BY THE SECOND CRUISE OF THE JAPANESE EXPEDITION OF DEEP SEA (JEDS-2)

$\operatorname{AUTHOR}(S)$ :

Nagata, Kizo

CITATION:

Nagata, Kizo. TWO NEW GAMMARIDEAN AMPHIPODS (CRUSTACEA) COLLECTED BY THE SECOND CRUISE OF THE JAPANESE EXPEDITION OF DEEP SEA (JEDS-2). PUBLICATIONS OF THE SETO MARINE BIOLOGICAL LABORATORY 1963, 11(1): 1-5

ISSUE DATE:

1963-07-20

URL:

http://hdl.handle.net/2433/175328

RIGHT: 


\title{
TWO NEW GAMMARIDEAN AMPHIPODS (CRUSTACEA) COLLECTED BY THE SECOND CRUISE OF THE JAPANESE EXPEDITION OF DEEP SEA (JEDS-2)*
}

\author{
Kızô NAGATA \\ Inland Sea Regional Fisheries Research Laboratory
}

With 2 Text-figures

While examining gammaridean amphipods collected by "Ryôfû-maru" in the area ranging $37^{\circ} 55^{\prime} \mathrm{N}$. to $42^{\circ} 26^{\prime} \mathrm{N}$. in Latitude, $143^{\circ} 25^{\prime} \mathrm{E}$. to $148^{\circ} 28^{\prime} \mathrm{E}$. in Longitude of Japan Tredch during September of 1959, the writer has identified the following eighteen species in total of all six collections by several gears, two of which belong to the Leucothoid and Paramphithoid groups seemed to be new to science. They are:

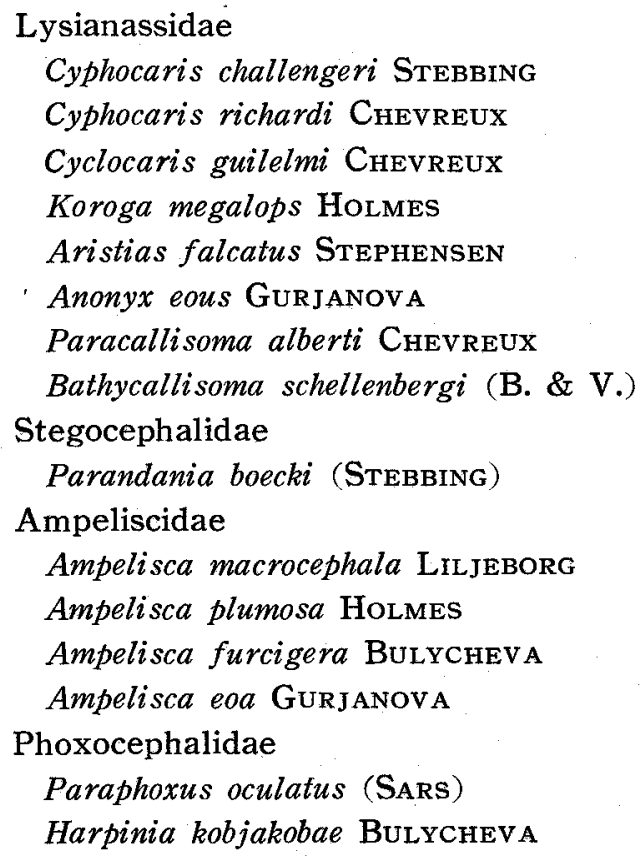

* JEDS Contribution No. 45.

Publ. Seto Mar. Biol. Lab., XI (1), 1963. (Article 1) 


\section{Leucothoidae \\ Leucothoe pacifica, sp. nov. \\ Paramphithoidae \\ Epimeria pelagica Birstein \& Vinogradov \\ Epimeria subcarinata, sp. nov.}

Recently, the oceanographic investigations of north-western part of the Pacific Ocean have been carried out extensively by the Russian ships, and a large number of bathypelagic gammaridean amphipods from the same area as ours have been reported by BIRSTEIN \& VinOGRADOv (1955, 1958, and 1960) which are much available for examining the present gammaridean collections. Now, only two new species are herein described. A general account of the Amphipoda collected will be described in detail, including the Hyperidean group (in charge of Dr. Haruhiko IRIE) in near future.

The writer wishes to acknowledge the opportunity given by the Biological Section of the Committee of the JEDS for assigning the examination of the Gammaridean group to the writer through the courtesy of Prof. Dr. Haruhiko IRIE of Nagasaki University who takes the charge of Order Amphipoda as a whole and for reading this manuscript. The writer is also deeply grateful to Prof. Dr. Huzio Utinomi of the Seto Marine Biological Laboratory of Kyoto University, for his constant aid and helpful advices in the study on this group, and for giving an opportunity of publishing this paper. The writer is also indebted to Mr. Yoshimasa ENомото of the Tôkai Regional Fisheries Research Laboratory, for his help in translating the Russian references into Japanese.

\section{Leucothoe pacifica, sp. nov.}

(Fig. 1)

Diagnosis: Comparing with SARS' figures for L. spinicarpa (1895, pls. 100, 101, fig. 1), the differences are as follows: Eyes could not be seen. Lateral lobes of head somewhat angular. A thin interantennal plate vertically running through the median line of the front of head and separating right and left antennae, forms a large triangular tooth below, its acute apex extending forwards nearly to the end of peduncular third article of antenna 2 . Asymmetrical lobe of upper lip in frontal view rather similar to that of $L$. uschakovi figured by GurJanova (1951, fig. 320). Epistome not so long and not so acute at apex, but never rounded as seen in L. uschakovi. Gnathopod 1, postero-proximal margin of article 2 setose; the apices of articles 5 and 7 not so delicately curved; article 7 relatively short, about one third as long as article 6. Gnathopod 2, posterior margin of articles 2 and 3 covered with many setae; article 6 rather more elongated. Coxae 1-4 somewhat narrower, particularly in coxa 4 of which the frontal margin slightly concave, and its lower 
angle bearing a small, acute point, whereas article 2 of peraeopods $3-5$ more broader; the lower hind margin in peraeopod 5 rather truncated. The third pleonal epimeron distinctly sinuate at the lower posterior corner. Otherwise, the new species nearly agrees with $L$. spinicarpa figured by SARS.

Material: St. B, off Kushiro, Hokkaidô, $42^{\circ} 40^{\prime}$ N. Lat., $144^{\circ} 30^{\prime}$ E. Long., $490 \mathrm{~m}$, Niino dredge, Sept. 17, 1959, one female specimen, $13 \mathrm{~mm}$ long (Holotype, Cat. No. 3084, preserved in writer's hand).

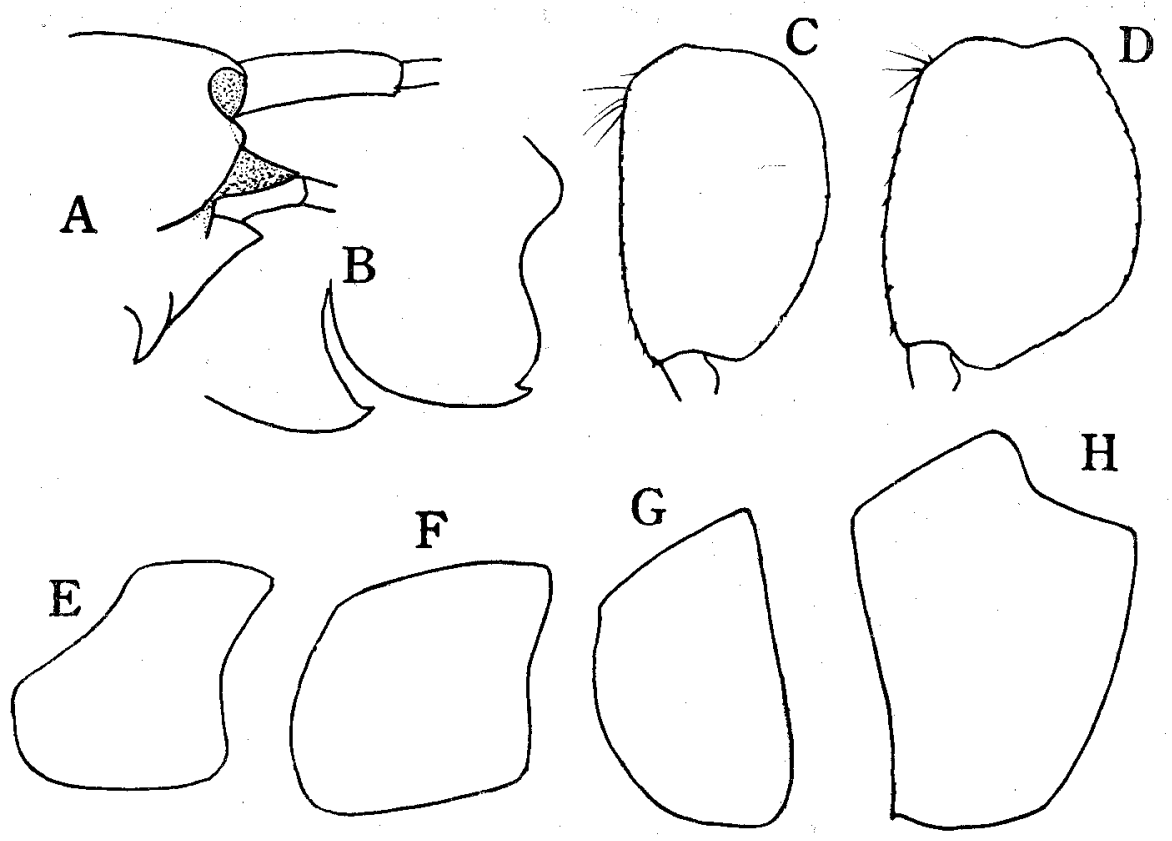

Fig. 1. Leucothoe pacifica sp. nov.

Female, $13 \mathrm{~mm}$ : A, front of head; B, epimeral plates 2 and $3 ; \mathrm{C}$ and $\mathrm{D}$, article 2 of peraeopods 3 and $5 ; \mathrm{E}-\mathrm{H}$, coxal plates $1-4$.

Remarks: The new species is closely related to $L$. spinicarpa, but lacks eyes in spite of being secured from such a relatively shallower depth of 490 meter. Two species of blind or nearly blind are hitherto known; L. uschakovi GurJanova (1. c.) from Greenland Sea, 3000 meter, and L. panpulco J. L. BARNARD (1961, p. 75, fig. 44) from depth of 3570 meter, off the Pacific coast of Panama, but this is distinguished from the former by antennae, coxa 1, gnathopod 1, epimeral plate 3 , and epistome; and from the latter by the entire wanting of eyes, the shape of coxae 1-4, of article 2 of peraeopods $3-5$, and of the inferoposterior angle of the third pleonal epimeron. 


\section{Epimeria subcarinata, sp. nov.}

(Fig. 2)

Diagnosis: Rostrum not attaining to the end of the peduncular article 1 of the first antenna. Peraeon segments lacking dorsal carina. Posterior carinae of pleon segments 1 and 2 weak, not ending in a tooth, while each of pleon segments 3 and 4 produced to an acute process. Dorsal depression on pleon segment 4 wide and shallow. Eyes could be only faintly traced in spirit. Coxa 4 anteriorly recurved, attenuated; posteriorly bearing a somewhat long and

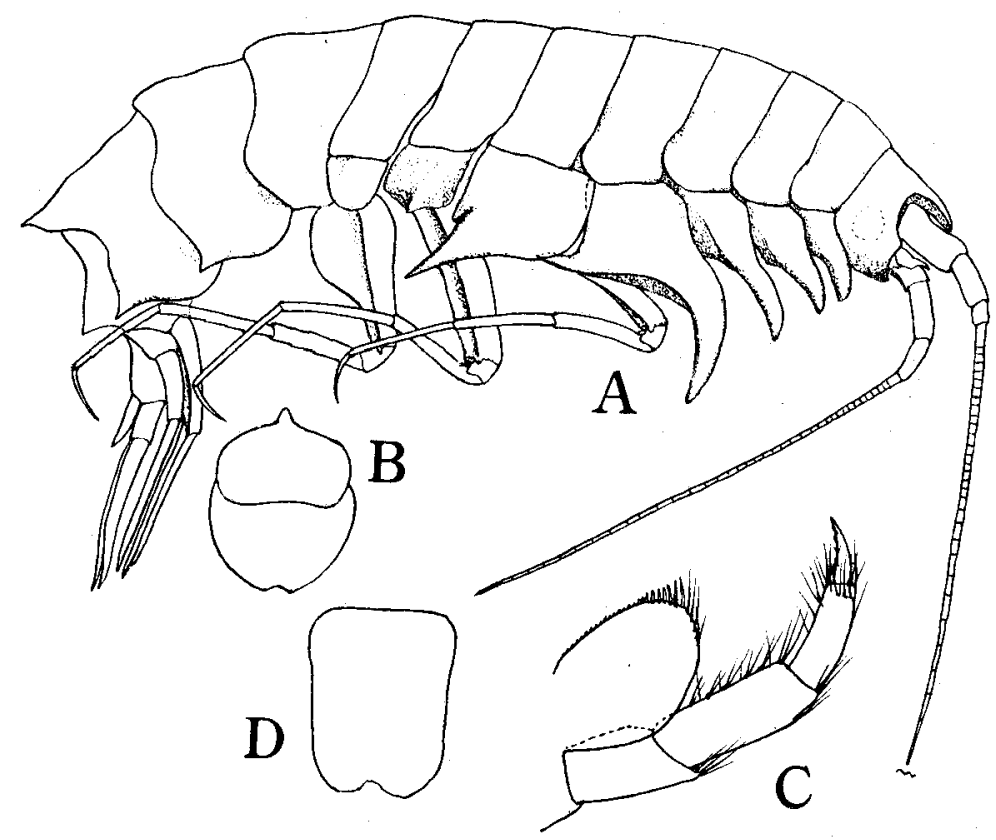

Fig. 2. Epimeria subcarinata sp. nov.

Female $23 \mathrm{~mm}$, Holotype: A, lateral view. Female, $25.3 \mathrm{~mm}: \mathrm{B}$, upper lip ; $\mathrm{C}$, maxillipedal palp; $\mathrm{D}$, telson.

blunt process. Coxa 5 acutely produced at the lower posterior corner. Pleonal epimera 1 and 2 with the hind margin largely bulging, but slightly convex on the third pleonal epimeron; pleonal epimera 2 and 3 with a tooth at the lower posterior corner, and bulging on the lpwer margin. Maxillipedal palp rather strong, its second article relatively long. Epistome with a small conical process at the distal end. Gnathopods like in E. pacifica Gurjanova (1955: 191-194, figs. 12-13). Peraeopods long and slender; peraeopods 3 and 4 with a straight posterior margin on article 2 ; article 2 of peraeopod 5 dilate at base, then 
abruptly narrowing to the distal end. Telson not narrowing towards the apex.

Material: St. S, off Onagawa near Sendai, $37^{\circ} 55^{\prime}$ N. Lat., $143^{\circ} 25^{\prime}$ E. Long., $2230 \mathrm{~m}$, beam trawl, Sept. 11, 1959. Total: 3 female specimens; Holotype, $23 \mathrm{~mm}$ long (Cat. No. 3372, preserved in writer's hand) ; two other ones, $21 \mathrm{~mm}$, and $25.3 \mathrm{~mm}$ in length.

Remarks: This is much closely related to $E$. pacifica (l.c.), but differs by the following characters; in E. pacifica, rostrum much elongated and reaching nearly to the distal end of peduncular third article of antenna 1 ; each of pleon segments 1-4 with a well developed dorsal projection; dorsal notch on pleon segment 4 narrow and steep; posterior process of coxa 5 nearly reaching to the posterior margin of the first pleonal epimeron; telson similar to the present new species, but narrowing distally ; and showing a somewhat different shape of pleonal epimera 1-3.

The writer is, however, uncertain whether this new species is essentially distinctive from $E$. pacifica or not, in spite of the differences mentioned above. E. pacifica is based on the adult female of $21 \mathrm{~mm}$ long secured from the slope of the Trench in depths of 1450-1530 meters, E. of Shikotan I., while the present specimens of all adult female, $21.0-25.3 \mathrm{~mm}$ long were taken from the depth of 2230 meter, off Onagawa. Both species were therefore collected from the pretty neighboring localities each other, but the differences would not be due to ones such as both age and sex.

\section{REFERENCES}

BARnard, J. L. 1961. Gammaridean Amphipoda from depths of 400 to 6000 meters. Galathea Repts., $5: 23-128,83$ figs.

Birstein, A. and M. E. Vinogradov 1955. Pelagicheskie gammaridy (Amphipoda, Gammaridea) Kurilo-Kamchatskoie vpadiny. Trudy Inst. Okean. Akad. Nauk SSSR, 12: 210-287, 35 figs., 4 tables.

- 1958. Pelagicheskie gammaridy (Amphipoda, Gammaridea) severozapadnoi chasti Tixogo Okeana. Ibid., 27 : 219-257, 17 figs., 1 table.

1960. Pelagicheskie gammaridy tropicheskoi chasti Tixogo Okeana. Ibid., 34: 165241,34 figs., 2 tables.

GuRJAnova, E. 1951. Bokoplavy morei SSSR i sopredel'nyx vod (Amphipoda, Gammaridea). Opred. po Faune SSSR, Izd. Zool. Inst. Akad. Nauk, 41: 1-1031, 705 figs.

1955. Novye vidy bokoplavov (Amphipoda, Gammaridea) iz severnoi chasti Tixogo Okeana. Trudy Zool. Inst. Akad. Nauk SSSR, 18: 166-218, 23 figs.

SARS, G. O. 1895. Amphipoda. An account of the Crustacea of Norway with short descriptions and figures of all the species, $1: 8$ and 711 pp., 240 pls., 8 suppl. pls. 